\title{
PENGEMBANGAN PERANGKAT PEMBELAJARAN FISIKA MODEL PROBLEM BASED LEARNING (PBL) UNTUK MELATIH KETERAMPILAN BERPIKIR KRITIS SISWA
}

\author{
Sulardi $^{1)}$, Mohamad Nur ${ }^{2)}$, Wahono Widodo ${ }^{3)}$ \\ ${ }^{1)}$ Mahasiswa Program Studi Pendidikan Sains, Program Pascasarjana Universitas Negeri Surabaya \\ ${ }^{2), 3}$ Dosen Pascasarjana Prodi Pendidikan Sains Univestitas Negeri Surabaya \\ E-mail: sulardi_melak@yahoo.co.id
}

\begin{abstract}
This developmental research aims to produce physics learning device using qualified Problem Based Learning model (PBL) (validity, practicality, and effectiveness) to practice students's critical thinking skills in the subject of rotational dynamics and the weight of the object point. This research was implemented into stages, namely device development using the 4-D model of Thiagarajan (1974) and learning device implementation for 4 meetings with 25 students of eleventh grade of the State senior high school 1 Muara Lawa, in the second semester the academic year 2014/2015 by using one group pretest-posttest design the results of the research was analyzed by using descriptive analysis techniques. The obtained data: validator assessment of the lesson plan (RPP), student's worksheet (LKS), Student's Books, and assessment sheets with valid category. Student's worksheet assessment and student's book also have a high degree of readability. Lesson plan feasibility with the score of 4.04 is well performed category. Student learning outcomes (knowledge, critical thinking skills, psychomotor skills and attitudes) is classically completed. All students got critical thinking improvement: 16\% (not skillful-less skillfull), $48 \%$ (not skillful-skillful), $36 \%$ (not skillful-very skillful). Based on the observation $65 \%$ of the learning was student's activity. The students responded the learning activities of PBL models positively.The research shows that the physics learning device using problem based learning model is valid, practical, and effective to train the students' critical thinking skills.
\end{abstract}

Keywords: Physics Learning, Problem Based Learning Model, Critical Thinking Skills.

Abstrak: Penelitian pengembangan ini bertujuan untuk menghasilkan perangkat pembelajaran fisika model Problem Based Learning (PBL) yang berkualitas (validitas, kepraktisan, dan keefektifan) untuk melatih keterampilan berpikir kritis siswa pada materi dinamika rotasi benda tegar dan titik berat benda. Penelitian ini dilaksanakan dalam dua tahap, yaitu pengembangan perangkat mengikuti rancangan 4-D model dari Thiagarajan (1974) dan dilanjutkan dengan tahap implementasi perangkat pembelajaran sebanyak 4 pertemuan terhadap 25 siswa kelas XI-IPA di SMA Negeri 1 Muara Lawa semester genap tahun pelajaran 2014/2015 dengan menggunakan rancangan one group pretest-posttest design sedangkan hasil penelitian dianalisis dengan teknik analisis deskriptif. Data hasil penelitian diperoleh: penilaian validator terhadap RPP, LKS, Buku Siswa, dan lembar penilaian dengan kategori valid. LKS dan Buku siswa juga memiliki tingkat keterbacaan yang tinggi. Penilaian keterlaksanaan RPP dengan skor 4,04 berkategori terlaksana dengan baik. Hasil belajar siswa (pengetahuan, keterampilan berpikir kritis, keterampilan psikomotor dan sikap) secara klasikal tuntas. Semua siswa mengalami peningkatan keterampilan berpikir kritis: $16 \%$ (tidak terampil-kurang terampil), $48 \%$ (tidak terampil-terampil), 36\% (tidak terampil-sangat terampil). Hasil pengamatan sebesar $65 \%$ dari pembelajaran adalah aktivitas siswa. Siswa memberikan respon yang positif terhadap kegiatan pembelajaran model PBL. Hasil penelitian menunjukkan bahwa perangkat pembelajaran fisika dengan model PBL telah valid, praktis, dan efektif untuk melatih keterampilan berpikir kritis siswa.

Kata kunci: Pembelajaran Fisika, Model Pembelajaran PBL, Keterampilan Berpikir Kritis.

\section{PENDAhUluan}

Kecakapan hidup (life skill) yang perlu dikembangkan melalui proses pendidikan adalah keterampilan berpikir. Berpikir diperlukan untuk mengembangkan sikap dan persepsi yang mendukung terciptanya kondisi kelas yang positif, untuk memperluas wawasan pengetahuan, untuk mengaktualisasikan kebermaknaan pengetahuan, dan untuk mengembangkan perilaku berpikir yang rasional.
Beberapa keterampilan berpikir yang dapat meningkatkan kecerdasan memproses dalam life skill adalah keterampilan berpikir kritis, keterampilan mengorganisir otak, dan keterampilan analisis.

Berpikir kritis adalah kemampuan belajar yang harus diajarkan pada peserta didik karena kemampuan ini sangat diperlukan dalam kehidupan (Schafersman, 1991). Selain itu kemampuan berpikir kritis adalah suatu proses berpikir yang dapat diterima akal reflektif, 
rasional dan bertanggung jawab yang diarahkan untuk memutuskan apa yang dikerjakan atau diyakini, dalam hal ini tidak sembarangan dalam menganalisis suatu permasalahan dan menarik suatu kesimpulan, tetapi hasil dari berpikir kritis adalah pada sebuah kesimpulan yang terbaik.

Mengapa berpikir kritis perlu diajarkan kepada siswa? Karena berpikir kritis yang diajarkan akan memberikan bekal yang baik untuk kehidupan masa depan siswa. Seorang guru yang mengajarkan sebuah definisi bukan hanya bertujuan untuk bisa dihafalkan oleh siswa saja dan mendapat nilai kemudian lulus, tetapi perlu diajarkan tentang arti dan kegunaan dari pelajaran yang diberikan. Hasil dari keterampilan berpikir kritis dan dikombinasikan dengan ilmu pengetahuan yang diperoleh siswa, maka akan sangat berguna bagi kehidupan masa depan siswa.

Kurikulum 2013 bermaksud untuk mengembangkan potensi dan karakter peserta didik memiliki sikap rasa ingin tahu, jujur, tanggung jawab, logis, kritis, analitis, dan kreatif. Siswa memiliki kemampuan dalam berpikir reflektif bagi penyelesaian masalah sosial di masyarakat. Mengembangkan keseimbangan antara pengembangan sikap spiritual dan sosial, rasa ingin tahu, kreativitas, kerja sama dengan kemampuan intelektual dan psikomotorik. Pola pembelajaran pada Kurikulum 2013 adalah penyempurnaan dari kurikulum sebelumnya, di mana pola pembelajaran yang berpusat pada guru menjadi pembelajaran berpusat pada peserta didik, pola pembelajaran pasif menjadi pembelajaran aktifmencari, pola pembelajaran pasif menjadi pembelajaran kritis (Permendikbud, 2013).

Berdasarkan hasil penelitian PISA

(Programme for International Student Assessment) 2012 dalam matematika, sains, dan membaca yang diselenggarakan Organisation for Economic Cooperation and Development, hasilnya Indonesia di peringkat ke-64 dari 65 negara yang disurvei. Asesmen internasional tersebut mengukur kecakapan siswa berusia 15 tahun dalam mengimplementasikan pengetahuan yang dimilikinya untuk menyelesaikan masalah-masalah dunia nyata. Mayoritas siswa Indonesia belum mencapai level 2 untuk matematika $(75,7 \%)$ dan sains $(66,6 \%)$. Lebih memprihatinkan, $42,3 \%$ siswa bahkan belum mencapai level kecakapan terendah (level 1) untuk matematika dan $24,7 \%$ untuk sains (Driana, 2013).

Keadaan ini dipertegas dengan hasil observasi penulis di salah satu SMA di Kabupaten Kutai Barat, dengan memberikan angket kepada 20 siswa terkait dengan kegiatan pembelajaran fisika, hasil analisis angket menggambarkan bahwa masih terdapat 30\% guru tidak menyampaikan tujuan pembelajaran pada saat awal kegiatan pembelajaran, 60\% guru tidak pernah menggunakan alat peraga dalam menunjang kegiatan pembelajaran, dan masih terdapat $30 \%$ guru mengajar tidak mengaitkan materi pelajaran dengan masalah autentik dalam kehidupan sehari-hari siswa. Hal ini mengindikasikan bahwa dalam kegiatan pembelajaran, guru masih belum melaksanakan kegiatan pembelajaran secara optimal untuk membantu siswa dalam membangun pengetahuan secara mandiri.

Penulis juga melakukan observasi dengan memberikan soal tes keterampilan berpikir kritis kepada 20 siswa kelas XII-IPA yang sudah pernah mendapatkan materi rotasi benda tegar dan titik berat benda. Hasil observasi diperoleh data bahwa dari 20 siswa ternyata hanya 3 orang siswa yang terampil dan mampu menjawab dengan benar, hal ini mengindikasikan bahwa kemampuan siswa dalam menganalisis berbagai persoalan yang menggunakan keterampilan berpikir masih rendah.

Persoalan di atas, khususnya dalam mengajarkan keterampilan berpikir kritis dapat diatasi dengan melatih siswa berpikir kritis melalui kegiatan pembelajaran. Guru sebagai tenaga pendidik perlu merancang pembelajaran yang dapat melatih kemampuan berpikir kritis siswa agar mencapai keberhasilan dalam belajar. Ada banyak pendekatan, strategi, metode dan model yang dapat diterapkan untuk melatih kemampuan berpikir kritis siswa dalam pembelajaran, salah satunya alternatif adalah dengan menggunakan model Problem Based Learning (PBL).

Esensi PBL adalah menyuguhkan berbagai situasi bermasalah yang autentik dan bermakna kepada siswa, yang berfungsi sebagai batu loncatan untuk investigasi dan penyelidikan siswa. PBL berusaha membantu siswa untuk menjadi pembelajar yang independen dan selfregulated. Dibimbing oleh guru yang senantiasa memberi semangat dan reward ketika mengajukan pertanyaan dan mencari sendiri solusi untuk berbagai masalah rill, kelak siswa belajar untuk melaksanakan tugasnya secara mandiri (Arends, 2008).

Kegiatan pembelajaran model PBL, siswa menjadi tokoh utama yang terlibat langsung dalam pembelajaran, bukan sekadar sebagai pendengar pasif terhadap semua informasi yang disampaikan oleh guru. PBL mengondisikan siswa untuk belajar berinteraksi dengan kelompok, mengaitkan pembelajaran dengan materi lain, dan melatih siswa berinkuiri untuk menemukan cara penyelesaian masalah yang tepat dan berpikir kritis. Dengan demikian, PBL sejalan dengan pembelajaran fisika karena PBL memberikan tahapan kepada siswa untuk dapat memecahkan masalah fisika yang ada dalam kehidupan sehari-hari berdasarkan konsep fisika.

Pembelajaran dengan menggunakan model PBL, pada bagian awal guru menyodorkan situasi bermasalah yang menarik untuk membangkitkan minat siswa 
dalam identifikasi permasalahan. Kemudian guru memberikan bantuan dalam mengorganisasi keterampilan kolaborasi di antara siswa untuk meneliti permasalahan dalam tim-tim studi kecil, mengumpulkan data dan eksperimen, mengembangkan hipotesis, memberikan solusi, mempresentasikan, menganalisis dan mengevaluasi proses mengatasi masalah.

Pembelajaran PBL (Graaff dan Kolmos, 2003) didasarkan pada latar belakang siswa, harapan, dan kepentingan. Hal ini agar siswa termotivasi untuk bekerja lebih keras dengan model PBL dibandingkan dengan metode pengajaran tradisional secara umum, siswa menghabiskan lebih banyak waktu pada studi mereka ketika bekerja dengan model PBL. Partisipasi siswa jauh lebih besar, karena ada hubungan antara pengajaran metode, kedalaman dan kompleksitas belajar. Siswa dapat diperkirakan akan mencapai tingkat analitis kompleks pemahaman melalui pekerjaan proyek, yang tidak akan mungkin dalam kelas konvensional. Bagian terpenting dari pembelajaran PBL adalah untuk memastikan bahwa siswa berada pada posisi untuk menggali setiap potensi yang dimiliki untuk kehidupan di masa depan mereka, ini adalah keterampilan yang diperlukan untuk semua siswa.

Hasil dari PBL (Ling, 2005) adalah untuk: mendorong pelajar untuk lebih aktif dan termotivasi, mendorong peserta didik menjadi pembelajar mandiri, membantu pelajar untuk mencapai tingkat mendalam pemahaman tentang pengetahuan yang relevan, dan mendorong peserta didik untuk mengembangkan beberapa keterampilan kunci termasuk pemecahan masalah, kerja tim, belajar sepanjang hayat, berpikir kritis dan komunikasi. Hasil penelitian yang dilakukan oleh Setyorini, Sukiswo, \& Subali, (2011) mengemukakan bahwa model PBL dapat meningkatkan kemampuan berpikir kritis siswa pada pembelajaran gerak lurus berubah beraturan, dimana $75 \%$ siswa memiliki kemampuan berpikir kritis dan 7,5\% siswa memiliki kemampuan berpikir sangat kritis.

Tujuan pendidikan dalam Kurikulum 2013 agar bisa tercapai, yaitu meningkatkan prestasi belajar siswa, melatihkan keterampilan berpikir kritis kepada siswa melalui pembelajaran di kelas, serta melihat berbagai kenyataan permasalahan dalam pendidikan saat ini, maka sudah selayaknya pola pembelajaran berorientasi pada pembentukan sikap spiritual dan sosial, intelektual serta keterampilan memecahkan masalah yang merupakan cerminan keterampilan berpikir kritis. Untuk memenuhi harapan ini dan mengingat masih minimnya perangkat pembelajaran berpikir kritis, maka diperlukan sebuah pengembangan perangkat pembelajaran untuk membelajarkan keterampilan berpikir kritis siswa yang nantinya diharapkan menjadi bekal kehidupan sehari-hari dan masa depan siswa.

Tujuan dan harapan ini agar dapat terlaksana, maka penulis mengembangkan suatu perangkat pembelajaran yang berorientasi pada upaya melatih keterampilan berpikir kritis siswa melalui model PBL. Melalui hasil desain pembelajaran ini, maka sangat besar harapan dari penulis untuk mewujudkan situasi pembelajaran yang dapat meningkatkan keterampilan berpikir kritis siswa melalui suatu masalah. Oleh karena itu, berdasarkan uraian latar belakang di atas maka penulis akan melakukan suatu penelitian dalam pengajaran fisika dengan judul: Pengembangan Perangkat Pembelajaran Fisika Model Problem Based Learning (PBL) untuk Melatih Keterampilan Berpikir Kritis Siswa.

\section{METODE PENELITIAN}

Penelitian ini merupakan penelitian pengembangan perangkat pembelajaran. Perangkat yang dikembangkan meliputi RPP, LKS, Buku Siswa dan Lembar Penilaian yang didesain dengan model PBL untuk melatih keterampilan berpikir kritis siswa. Desain pengembangan perangkat yang dikembagkan mengikuti rancangan 4-D model yang terdiri dari empat tahap, yaitu Define, Design, Develop dan Disseminate. Pada penelitian ini hanya dilakukan pada 3 tahapan saja, yaitu Define, Design, dan Develop. Hal ini karena keterbatasan waktu dan faktor pendukung yang lain.

Subjek uji coba perangkat adalah siswa kelas XIIPA SMAN 1 Muara Lawa semester genap tahun pelajaran 2014/2015. Desain uji coba perangkat pembelajaran dalam pengembangan ini menggunakan model One Group Pretest-Posttest Design.

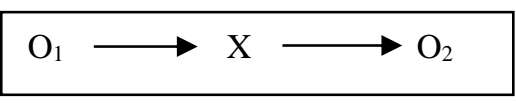
$\mathrm{O}_{1} \quad$ Uji awal (pretest)
$\mathrm{O}_{2} \quad$ Uji akhir (posttest)
$\mathrm{X} \quad$ Perlakuan pembelajaran model PBL

Pengumpulan data dilakukan dengan menggunakan metode tes, metode observasi dan metode angket. Metode tes digunakan untuk mengetahui hasil belajar berpikir kritis siswa setelah mengikuti pembelajaran dengan model PBL, metode observasi digunakan untuk mengetahui keterlaksanaan pembelajaran, aktivitas siswa, sedangkan metode angket digunakan untuk mengetahui validitas perangkat dan respon siswa setelah mengikuti pembelajaran.

Data hasil validasi perangkat pembelajaran dianalisis dengan menggunakan analisis deskriptif kualitatif. Data keterlaksanaan RPP, aktivitas siswa dan respon siswa yang diperoleh dianalisis dengan analisis deskriptif kualitatif dengan persentase. Data hasil belajar siswa ditentukan berdasarkan penilaian acuan patokan. Hasil tes keterampilan berpikir kritis dianalisis 
dengan menggunakan rubrik keterampilan berpikir kritis dengan kategori; 1) tidak terampil; 2) kurang terampil; 3) terampil; 4) sangat terampil. Data hasil pretest dan posttest kemudian dianalsis dengan menggunakain $N$-gain.

Hasil pengembangan perangkat pembelajaran telah diujicobakan oleh penulis pada kelas terbatas sebanyak 10 Siswa di SMA Negeri 1 Muara Lawa. Hasil pengamatan guru pengamat terhadap keterlaksanaan RPP sebersar 3,98 artinya terlaksana dengan baik. Aktivitas siswa aktif, sebanyak 67\% kegiatan pembelajaran dilakukan oleh siswa secara mandiri. Hasil posttest menunjukan 90\% siswa tuntas dan siswa juga mengalami peningkatan keterampilan berpikir kritis. Respon siswa juga sangat positif dan siswa mengharapkan agar perangkat pembelajaran dan pembelajaran dengan model PBL dapat diterapkan di sekolah. Hasil uji coba I dan adanya kendala-kendala yang ditemui dan dapat diatasi oleh penulis di jadikan sebagai pedoman untuk melakukan perbaikan terhadap perangkat-perangkat yang telah dikembangkan, sehingga pada uji coba II selanjutnya dapat berhasil dan terlaksana dengan baik (Sulardi, 2014).

\section{HASIL PENELITIAN DAN DISKUSI}

\section{A. Validitas Perangkat Pembelajaran}

Perangkat pembelajaran yang telah dikembangkan dalam penelitian ini meliputi; RPP, LKS, Buku Siswa dan Lembar Penilaian, selanjutnya divalidasi oleh validator yang ahli dibidangnya. Hasil validasi dapat dilihat pada Tabel 1 berikut:

Tabel 1. Validitas Perangkat Pembelajaran

\begin{tabular}{|l|l|l|l|}
\hline No & Perangkat & $\begin{array}{l}\text { validi } \\
\text { tas }\end{array}$ & $\begin{array}{l}\text { Reliab } \\
\text { ilitas }\end{array}$ \\
\hline 1 & RPP & 3,70 & $91,8 \%$ \\
\hline 2 & LKS & 3,78 & $87 \%$ \\
\hline 3 & Buku Siswa & 3,93 & $91 \%$ \\
\hline 4 & Lembar Penilaian \\
\hline & a. Hasil belajar produk & 3,60 & $92 \%$ \\
\hline & . Keterampilan berpikir kritis & 3,90 & $92 \%$ \\
\hline & . Keterampilan psikomotor & 4,00 & $100 \%$ \\
\hline & . Sikap & 4,00 & $100 \%$ \\
\hline
\end{tabular}

Pada Tabel 1. diperoleh hasil penilaian validitas perangkat pembelajaran oleh validator. Perangkat pembelajaran dikatakan valid jika skor minimal 2,60 (Ratumanan \& Laurens, 2006) dan dikatakan reliabel jika nilai reliabilitasnya $\geq 75 \%$ (Borich, 1994). Berdasarkan nilai yang diperoleh dari validator, maka perangkat yang telah dikembangkan valid dan reliabel. Perangkat yang dikembangkan didesain dengan model pembelajaran PBL yang diawali dengan membimbing dan mengorientasi siswa terhadap masalah-masalah yang autentik, kemudian mengorganisasi siswa dalam belajar, membantu siswa secara individu atau kelompok dalam melaksanakan penelitian, mengembangkan dan menyajikan hasil karya, dan menganalisis dan mengevaluasi proses pemecahan masalah.

Hasil penilaian terhadap LKS dan Buku Siswa juga memiliki tingkat keterbacaan yang tinggi, yang dideskripsikap pada Gambar 1 dan 2 berikut:
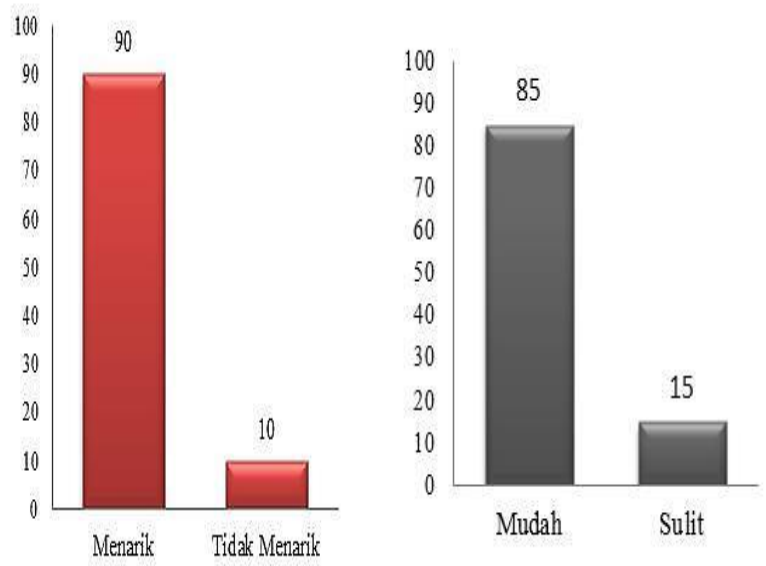

Gambar 1. Daya Tarik dan Tingkat Kemudahan Siswa dalam Memahami LKS

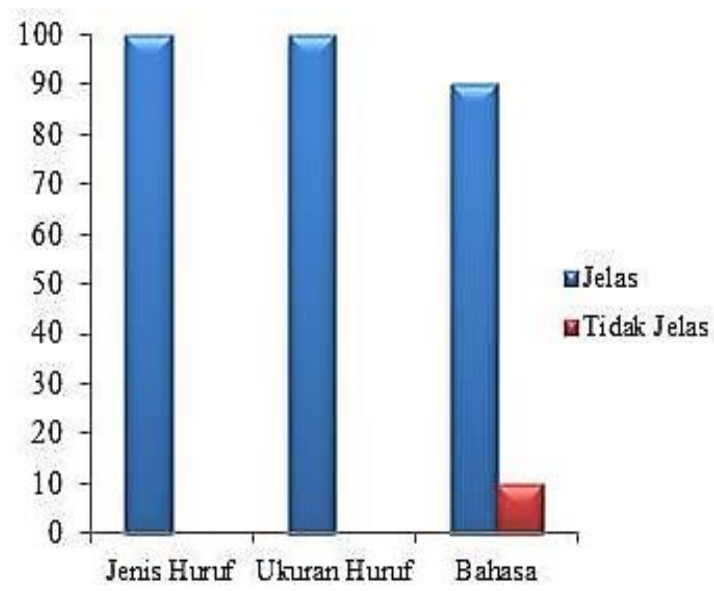

Gambar 2. Persentasi Kejelasan LKS

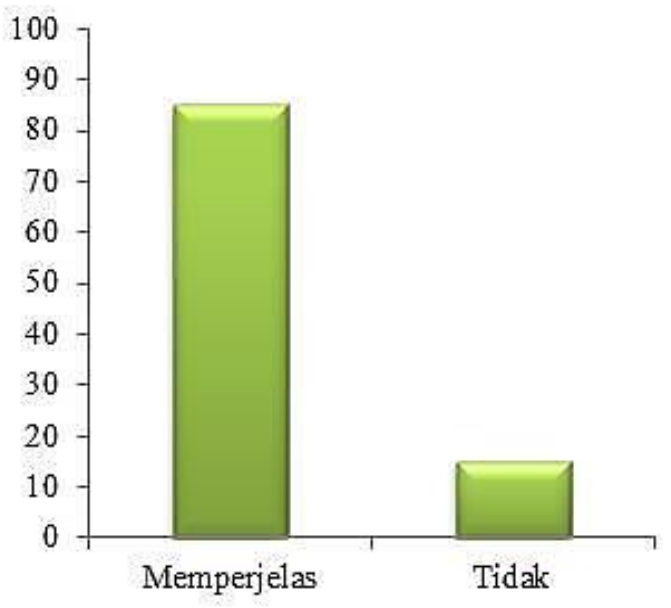

Grafik 3. Keterjelasan Ilustrasi/Gambar LKS 


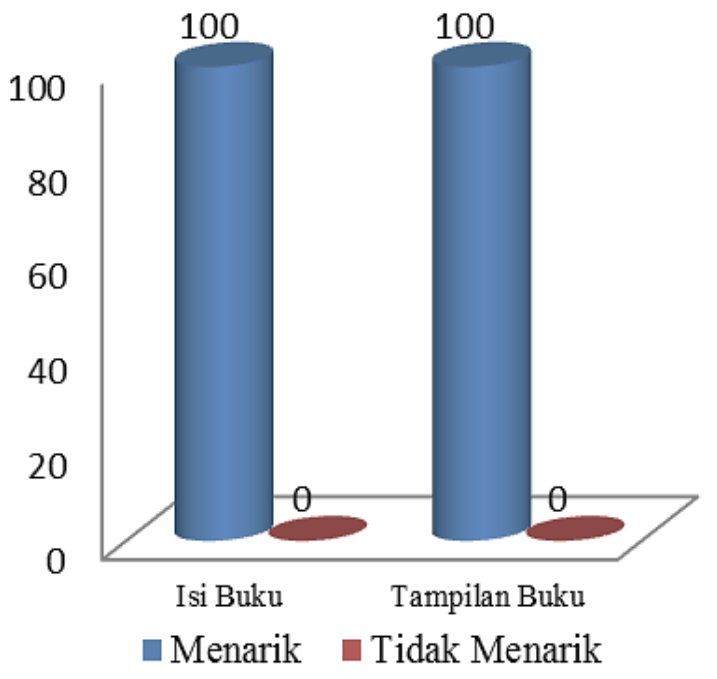

Gambar 4. Ketertarikan Buku Ajar

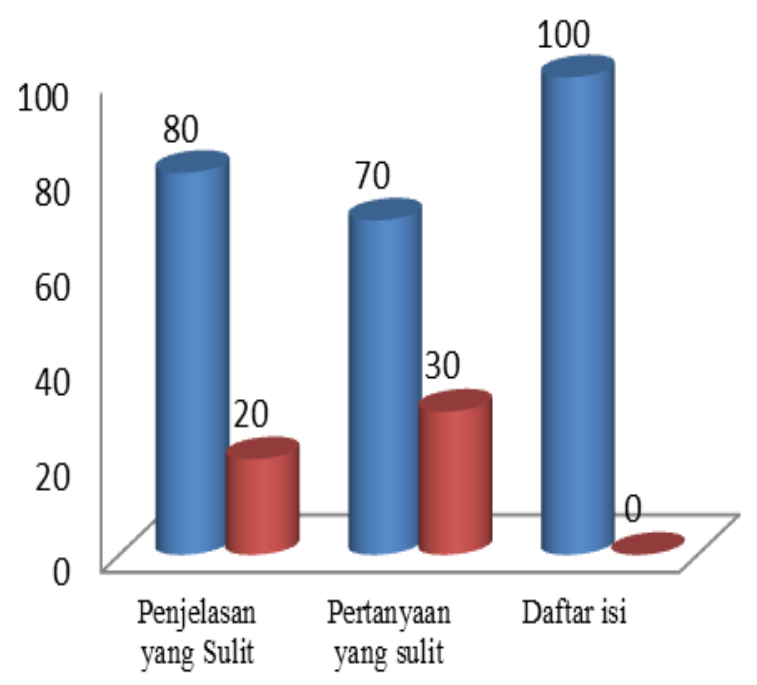

- Tidak Ada = Ada

Gambar 5. Tingkat Pemahaman Siswa Terhadap Buku Ajar

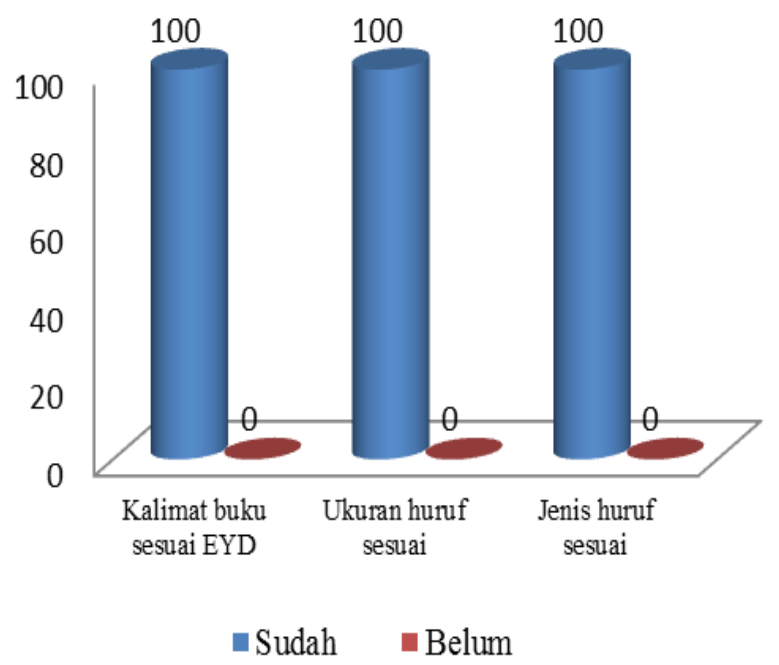

Gambar 6. Format Buku Ajar

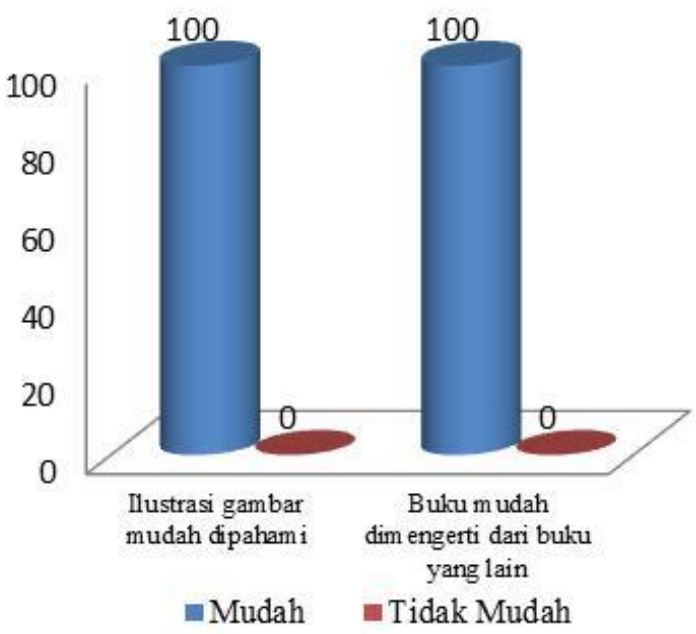

Gambar 7. Keterjelasan Ilustrasi/Gambar Buku Ajar

\section{B. Keterlaksanaan Pembelajaran}

Keterlaksanaan pembelajaran fisika dengan model PBL diamati oleh dua guru pengamat dan hasilnya dideskripsikan pada Gambar 8. berikut:

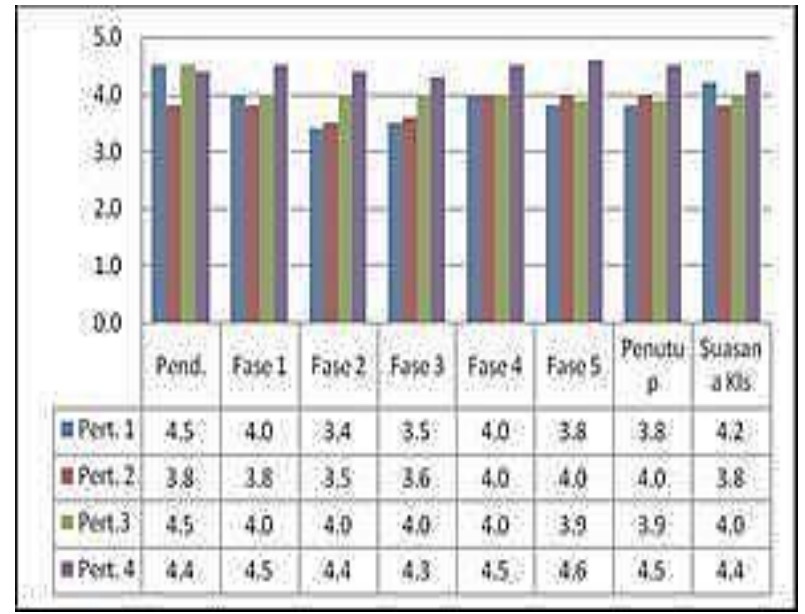

Gambar 8. Hasil Pengamatan Keterlaksanaan Pembelajaran dengan Model PBL

Penilaian pengamat terhadap keterlaksanaan pembelajaran model PBL diperoleh rerata skor nilai uji coba II adalah 4,04 dengan kategori terlaksana dengan baik.

Siswa mampu menyelesaikan soal pada tahap pemberian contoh dan latihan soal yang menggunakan pengetahuan prosedural seperti menentukan momen gaya dan momen inersia yang terdiri dari satu persamaan, tetapi jika menggunakan dua atau lebih persamaan siswa mengalami kesulitan. Hasil penelitian yang sama dijelaskan oleh (Rusli, 2013), bahwa pada saat siswa dihadapkan dengan pengetahuan prosedural yang melibatkan tiga buah persamaan, maka siswa sudah mengalami kesulitan dalam menentukan variabel yang akan diketahui. Seperti menentukan percepatan dua buah benda yang menggelinding yang melibatkan persamaan momen gaya, momen inersia dan hukum II Newton. 
Kegiatan pembelajaran dengan model PBL yang telah dilakukan pada pertemuan I, II, III dan IV, pada fase 3: membantu siswa secara individu atau kelompok dalam melaksanakan percobaan, di mana pada fase ini membutuhkan waktu yang banyak dan guru harus lebih intensif dalam membimbing siswa, karena siswa belum terbiasa dalam mengembangkan hipotesis, menentukan variabel kontrol, variabel manipulasi, variabel respon dan menganalisis data percobaan. Pada fase 3 siswa juga dibimbing untuk merumuskan maslah, membuat hipotesis, melaksanakan eksperimen, menganalisis dan dan menarik kesimpulan.

\section{Aktivitas Siswa}

Aktivitas siswa yang terjadi selama proses pembelajaran diamati oleh dua guru pengamat, dan hasilnya dideskripsikan pada Gambar 4 berikut:

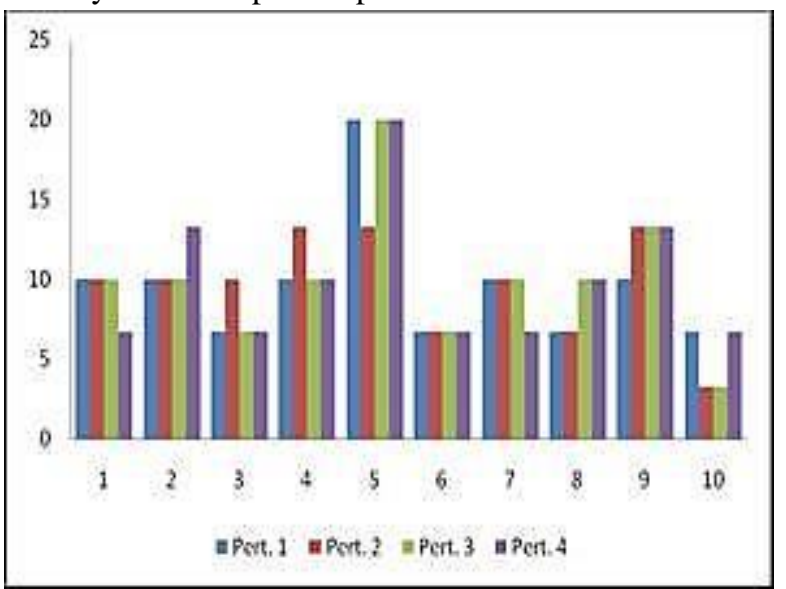

Gambar 9. Aktivitas Siswa dalam Pembelajaran Model PBL

Aspek aktivitas siswa:

1. Membaca (mencari informasi dan sebagainya)

2. Mendiskusikan tugas

3. Mencatat

4. Mendengarkan penjelasan guru

5. Melakukan pengamatan, percobaan, atau bekerja

6. Berdo'a sesuai dengan agama dan keyakinan

7. Bertanya pada teman dan guru

8. Menyampaikan pendapat

9. Bekerjasaman dalam kelompok

10. Perilaku tidak relevan.

Aktivitas siswa yang dominan dalam mengikuti proses pembelajaran, antara lain: membaca(mencari informasi), mendiskusikan tugas, melakukan pengamatan dan percobaan, bertanya pada guru dan teman, menyampaikan pendapat, dan bekerja sama dalam kelompok. Waktu belajar sebanyak $65 \%$ digunakan untuk keenam aktivitas siswa tersebut, data ini menjelaskan bahawa kegiatan pembelajaran yang dilakukan berpusat pada siswa.

\section{Hasil Belajar Siswa}

Hasil belajar siswa meliputi tes hasil belajar kognitif, psikomotor, dan afektif. Hasil analisis ketuntasan hasil belajar siswa pada aspek kognitif adalah $84 \%$, hasil belajar keterampilan $88 \%$ dan hasil belajar sikap $100 \%$. Hasil belajar secara keseluruhan memiliki ketuntasan individual sebesar $84 \%$ dan secara klasikal dikatakan tuntas karena standar ketuntasan klasikal $\geq 80 \%$, hal ini menunjukkan bahwa proses pembelajaran dengan menggunakan model PBL berhasil membuat siswa mencapai standar kompetensi dengan pencapaian indikator yang diharapkan dalam proses pembelajaran.

Hasil belajar pengetahuan pada tahap implementasi dengan ketuntasan individual sebesar $84 \%$ (21 siswa) tuntas, dan 16\% (4 siswa) tidak tuntas. Keempat siswa yang tidak tuntas, memiliki hasil tes pengetahuan dengan nilai yang rendah, sealin itu pengamatan dari pengamat terhadap siswa tersebut juga menunjukan kompetensi keterampilan yang rendah. Pengamatan yang peneliti lakukan terhadap keempat siswa tersebut memang memiliki tingkat disiplin yang kurang, dalam 4 kali pertemuan siswa tersebut selalu datang terlambat dan kurang antusias dalam kegiatan belajar belajar.

Hasil belajar keterampilan siswa yang diamati dalam proses pembelajaran terdiri dari menggunakan dan membaca skala alat dengan teliti, mengukur, melaksanakan prosedur percobaan, dan merencanakan percoabaan titik berat benda. Hasil belajar sikap yang diamati dalam proses pembelajaran terdiri dari dua, yaitu sikap spiritual dan sosial (Depdikbud, 2013). Sikap piritual meliputi: berdoa; mengucapkan salam; mengucapkan syukur; konsisten antara lisan dan perbuatan. Sikap sosial meliputi: bersikap jujur dan disiplin; memberikan argumen; bertanya, berpendapat dan menjawab pertanyaan; dan bekerja sama dalam kelompok. Pembelajaran menggunakan model PBL juga mendukung aspek keterampilan dan sikap, sehingga ketuntasan tersebut dapat terwujud karena indikator-indikator keterampilan dan sikap dilatihkan dalam pembelajaran.

\section{E. Hasil Belajar Keterampilan Berpikir Kritis}

Hasil tes belajar keterampilan berpikir kritis pada saat pretest semua siswa berada pada kategori tidak terampil, kemudian setelah dilakukan pembelajaran sebanyak 4 kali pertemuan dan dilakukan posttest semua siswa mengalami perubahan keterampilan berpikir kritis. Siswa dikatakan tuntas dan terampil, jika mencapai skor minimal 2,51. Semua siswa mengalami perubahan peningkatan keterampilan berpikir kritis, dan perubahan paling besar pada kategori tidak terampil menjadi terampil. Peningkatan tersebut terjadi karena dalam pembelajaran dengan menggunakan model PBL 
memotivasi dan memfasilitasi siswa dalam melatih keterampilan berpikir kritis. Perubahan keterampilan berpikir kritis dapat dilihat pada Tabel 2 berikut:

Tabel 2. Perubahan Keterampilan Berpikir Kritis Siswa

\begin{tabular}{|c|c|c|c|}
\hline \multirow[b]{2}{*}{ No } & \multirow{2}{*}{$\begin{array}{l}\text { Perubahan } \\
\text { Keterampilan Berpikir } \\
\text { kritis }\end{array}$} & \multicolumn{2}{|c|}{ Uji Coba II } \\
\hline & & $\begin{array}{l}\text { Jumlah } \\
\text { Siswa }\end{array}$ & $\begin{array}{c}\text { Persentase } \\
(\%)\end{array}$ \\
\hline 1 & $\begin{array}{lll}\text { Tidak } & \text { Terampil } & - \\
\text { Kurang Terampil } & \end{array}$ & 4 & 16 \\
\hline 2 & $\begin{array}{lll}\text { Tidak Terampil } & - \\
\text { Terampil } & & \\
\end{array}$ & 12 & 48 \\
\hline 3 & $\begin{array}{l}\text { Tidak Terampil - Sangat } \\
\text { Terampil }\end{array}$ & 9 & 36 \\
\hline \multicolumn{2}{|c|}{ Jumlah } & 25 & 100 \\
\hline
\end{tabular}

Persentase perubahan keterampilan berpikir kritis pada Tabel 2 dapat dideskripsikan pada Gambar 5 berikut:

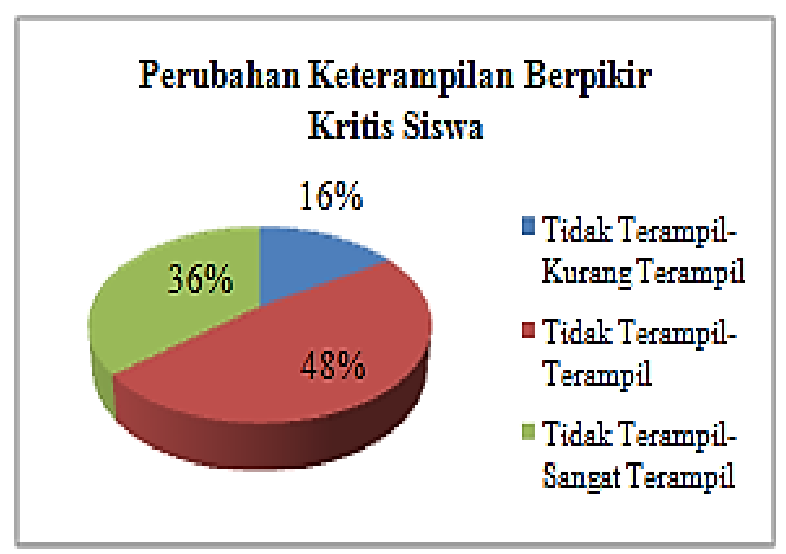

Gambar 10. Perubahan Keterampilan Berpikir Kritis Siswa

Pada penelitian ini ingin diketahui apakah model PBL dapat melatihkan keterampilan berpikir kritis siswa. Screven dan Paul (dalam Dennis, 2007) menyatakan:

"Berpikir kritis adalah sebagai proses disiplin cerdas dari konseptualisasi, penerapan, analisis, sintesis dan evaluasi aktif dan berketerampilan yang dikumpulkan atau dihasilkan oleh observasi, pengalaman, refleksi, penalaran atau komunikasi sebagai sebuah penuntun menuju kepercayaan dan aksi"

Pendapat Screven dan Paul (dalam Dennis, 2007) dapat diketahui bahwa untuk melatih keterampilan berpikir kritis, sebaiknya di dalam proses pembelajarannya melibatkan siswa untuk berpikir tingkat tinggi seperti menganalisis, mensintesis, memprediksi dan merancang sesuatu dalam mempelajari materi atau konsep tertentu.

Model pembelajaran yang digunakan dalam penelitian ini adalah model PBL yang disinyalir dapat melatih keterampilan berpikir kritis siswa (Arends, 2008). Hal ini tergambar dari tiap-tiap fase dalam RPP dengan model PBL yang menuntut siswa untuk berpikir secara kritis dan logis dalam setiap langkah-langkah penyelidikan, yaitu mulai dari merumuskan masalah, merumuskan hipotesis, mengumpulkan data, menyusun kesimpulan dan melakukan refleksi terhadap kesimpulan yang dibuat. LKS yang disusun juga mengajarkan siswa untuk melakukan langkah-langkah penyelidikan dengan keterampilan proses dan keterampilan berpikir kritis.

Hasil tes awal (pretest) berpikir kritis semua siswa (100\%) berada pada kategori tidak terampil pada hasil uji coba II. Hasil yang sama juga terlihat pada hasil penelitian-penelitian yang terdahulu di antaranya: (1) Penelitian Rasmawan (2013), hasil uji awal (pretest) semua siswa atau $100 \%$ siswa tidak terampil, (2) Penelitian Rusli (2013), hasil uji awal (pretest) semua siswa atau $100 \%$ siswa tidak terampil.

Mencermati dari data hasil penelitian yang ada menjelaskan, bahwa keterampilan berpikir kritis siswa tidak tiba-tiba bisa menyelasikan suatu permasalahan yang baru. Sebagaimana pendapat Screven dan Paul (dalam Dennis, 2007) bahwa keterampilan berpikir kritis perlu dilatih dari berbagai macam proses disiplin cerdas dalam tahapan pembelajaran. Ennis (dalam Hassoubah, 2004) menjelaskan bahwa berpikir kritis adalah kemampaun berpikir rasional dan reflektif yang difokuskan pada apa yang diyakini atau yang dilakukan. Rasional berarti memiliki keyakinan dan pandangan yang didukung oleh bukti standar, aktual, cukup dan relevan. Sedangakn reflektif berarti mempertimbangkan secara aktif, tekun dan hati-hati sebelum mengambil keputusan. Melatih keterampilan berpikir kritis siswa sampai pada kategori sangat terampil khususnya pada siswa yang memiliki set mental penghambat berpikir kritis tidak cukup hanya dalam beberapa kali pertemuan, melainkan membutuhkan waktu lama untuk membiasakan dan melatih keterampilan berpikir kritis siswa. Hal ini didukung oleh hasil penelitian yang dilakukan Robb Wass (2011) yang menyatakan bahwa dibutuhkan waktu panjang sekitar dua sampai tiga tahun untuk merubah set mental siswa yang telah lama terbentuk sehingga siswa mampu mengintegrasikan ideide mereka dan menerapkan berpikir kritis untuk hal yang baru.

\section{F. Respon Siswa}

Sebagian besar siswa memberikan respon positif terhadap pembelajaran dengan model PBL untuk melatih keterampilan berpikir kritis. Hal tersebut berarti siswa tertarik apabila pembelajaran dengan model PBL diterapkan dalam pembelajaran fisika. Ketertarikan tersebut diharapkan dapat mendorong, menginspirasi, dan membiasakan siswa menggunakan permasalahan atau terbiasa menanggapi serta menyelesaikan masalah sehari-hari. 
Rangkuman respon siswa dapat dilihat pada Tabel 3 berikut:

Tabel 3. Respon Siswa pada Pembelajaran Model PBL

\begin{tabular}{|c|l|c|c|c|c|}
\hline \multirow{2}{*}{ No } & \multicolumn{2}{|c|}{ Respon Siswa } & \multicolumn{4}{|c|}{ Pendapat Responden } \\
\cline { 3 - 6 } & $\begin{array}{c}\text { Sangat } \\
\text { Tertarik }\end{array}$ & Cukup Tertarik & $\begin{array}{c}\text { Kurang } \\
\text { Tertarik }\end{array}$ & $\begin{array}{c}\text { Tidak } \\
\text { Tertarik }\end{array}$ \\
\hline 1 & $\begin{array}{l}\text { Ketertarikan komponen } \\
\text { pembelajaran }\end{array}$ & $48 \%$ & $44 \%$ & $8 \%$ & $0 \%$ \\
\hline \multicolumn{2}{|l|}{} & Sangat Baru & Cukup Baru & Kurang Baru & Tidak Baru \\
\hline 2 & $\begin{array}{l}\text { Keterbaruan komponen } \\
\text { pembelajaran }\end{array}$ & $44,8 \%$ & $48 \%$ & $4 \%$ & $3,2 \%$ \\
\hline \multicolumn{2}{|l|}{} & $\begin{array}{l}\text { Sangat } \\
\text { Mudah }\end{array}$ & Cukup Mudah & Kurang Mudah & $\begin{array}{c}\text { Tidak } \\
\text { Mudah }\end{array}$ \\
\hline 3 & $\begin{array}{l}\text { Kemudahan memahami } \\
\text { komponen pembelajaran }\end{array}$ & $33,6 \%$ & $50,4 \%$ & $12 \%$ & $4 \%$ \\
\hline \multicolumn{2}{|l|}{} & Sangat Jelas & Cukup Jelas & Kurang Jelas & Tidak Jelas \\
\hline 4 & $\begin{array}{l}\text { Bimbingan dan penjelasan } \\
\text { guru }\end{array}$ & $58 \%$ & $38 \%$ & $4 \%$ & $0 \%$ \\
\hline \multicolumn{2}{|l|}{} & $\begin{array}{l}\text { Sangat } \\
\text { Mudah }\end{array}$ & Cukup Mudah & Sulit & $\begin{array}{c}\text { Sangat } \\
\text { Sulit }\end{array}$ \\
\hline 5 & $\begin{array}{l}\text { Keterampilan berpikir } \\
\text { kritis }\end{array}$ & $19 \%$ & $59 \%$ & $20 \%$ & $2 \%$ \\
\hline
\end{tabular}

Respon tersebut menunjukkan bahwa siswa dapat menerima dengan baik semua komponen pembelajaran yang meliputi buku siswa, LKS, materi pembelajaran, suasana belajar dan cara guru mengajar. Hal tersebut menunjukkan bahwa setiap pertemuan, siswa menggunakan buku siswa sebagai dasar pencarian informasi-informasi untuk menyelesaikan tugas, masalah, dan pertanyaan-pertanyaan percobaan, serta eksperimen yang terdapat dalam LKS.

Respon siswa terhadap komponen berpikir kritis didapatkan hasil, masih ada siswa yang meyatakan sulit terhadap keterampilan berpikir kritis, tetapi sebagian besar siswa menyatakan cukup mudah mempelajari dan memahami keterampilan berpikir kritis, hal tersebut berarti siswa tertarik apabila pembelajaran dengan model PBL untuk melatih keterampilan berpikir kirits untuk diterapkan dalam pembelajaran fisika.

\section{KESIMPULAN}

Berdasarkan hasil uji coba perangkat, analisis, diskusi, pembahasan dan temuan-temuan penelitian maka secara umum dapat disimpulkan bahwa perangkat pembelajaran fisika model PBL yang dikembangkan valid, praktis dan efektif untuk melatih keterampilan berpikir kritis siswa.

\section{REFERENSI}

Arends, R. (2008). Learning to teach, McGraw Hill Companies.
Borich, G.D. (1994). Observation skill for effective teaching. USA: Macmillan Publishing Company.

Dennis. F. K, 2007. Menguak rahasia berpikir kritis dan kreatif. Jakarta: Prestasi Pustakarya.

Driana, E. (2013). Menyikapi hasil PISA 2012. Tulisan dipublikasikan pada Koran Kompas. Jakarta.

Eggen, P. dan Kauchack, D. (2012). Strategi dan Model pembelajaran, mengajarkan konten dan keterampilan berfikir. Jakarta: Indeks.

Eldy, E.F., dan Sulaiman, F. (2013) "The role of PBL in improving physics students creative thinking and its imprint on gender". University Malaysia Sabah: International Journal of Education and Research. Vol. 1 No. 6.

Eldy, E.F., dan Sulaiman, F. (2013) "The Capability of Integrated Problem-Based Learning in Improving Students"e Level of Creative-Critical Thinking". University Malaysia Sabah: International Journal of Education, e-Business, e-Management and e-Learning. Vol. 3 No. 4.

Ennis, R.H. (1996). Critical thinking. United States of America: Prentice Hall. 
Fisher, A. (2007). Berfikir Kritis. Cambridge University Press.

Gallagher, S. A., dan Gallagher, J.J. (2013) "Using problem-based learning to explore unseen academic potential". Purdue University: Interdisciplinary Journal of Problembased Learning. Vol. 7, pp. 111-131.

Gokhale, A.A. (1995). "Collaborative learning enhaces critical thinking". United States: Journal of Technology Education. Vol. 7 No. 1, pp. 1-5.

Graaff, E. \& Kolmos, A. (2003). "Characteristics of problem based learning". Tempus Publications: International Journal Engng Ed. Vol. 19 No. 5, pp. 657-662.

Hassoubah, Z.I. (2004). Developing creative and critikal thinking skills, cara berfikir kreatif dan kritis. Bandung: Penerbit Nuansa.

Langrehr, J. (2011). "New methods for teaching anf testing inventive, inquisitive, and judgmental thinking". Malaysia: Journal International Confrence of Teaching and Learning.

Ling, Y. (2005). Application of modern teaching strategies in physics teaching. Beijing: Tsinghua University: The China Pepers.

Nur, M. (1998). Teori belajar prilaku. Surabaya: Institut Keguruan dan Ilmu Pendidikan.

Nur, M. (2011). Model pembelajaran berdasarkan masalah. Surabaya: Universitas Negeri Surabaya: Pusat Sains dan Matematika Sekolah (PSMS).

Nur, M. dan Wikandari, P.R., (2008). Pengajaran berpusat kepada siswa dan pendekatan kontruktivis dalam pengajaran. Surabaya: PSMS Unesa.

Rasmawan, R. (2013). Memberdayakan keterampilan berfikir kritis siswa sma melalui model pembelajaran berbasis inquiri pada metri laju reaksi. Unesa: Tesis tidak diterbitkan.
Ratumanan, G.T. dan Laurens. (2011). Evaluasi hasil belajar pada tingkat satuan pendidikan. Surabaya: Unesa Unversity Press.

Rob Wass. (2011). Scaffolding critical thinking in the zone of proximal development. Higher Education Research \& Development, hal 317-328.

Rusli, M. A. (2012). "Pembelajaran fisika melalui pemrosesan top down berbasis scaffolding untuk melatihkan keterampilan berfikir kritis". Unesa: Jurnal Penelitian Pendidikan Sains Unesa. Vol. 1 No. 3, pp. 45-50.

Schafersaman, S. D. (1991). Introduction to critical

thinking.Websitehttp//www.freeinquiry.co $\mathrm{m}$ /critical-thinking.html. Diakses Mei 2014.

Setyorini, U., Sukiswo, S. E.,\& Subali, B. (2011). "Penerapan model problem based learning untuk meningkatkan kemampuan berpikir kritis siswa SMP”. Jurnal Pendidikan Fisika Indonesia. Vol. 7, pp. 52-56.

Sugiyono, (2013). Metode penelitian pendidikan (pendekatan kuantitatif, kualitatif dan $R \& D)$. Bandung. Alfabeta.

Sulardi, (2014). Pengembangan perangkat pembelajaran fisika model problem based learning untuk melatih keterampilan berpikir kritis siswa. Unesa: Makalah komprehenshif tidak diterbitkan.

Szozoda, A. (2007). Investigating problem based learning in the science classroom. Mathematical and Computing Sciences Departement: Thesis.

Thiagarajan, S.,Semmel, D.S., \& Semmel, M.I. (1974). Instructional development for training teachers of exceptional children. Indiana: Indiana University. 